\title{
Pengaruh Literasi Baca Tulis dalam Meningkatkan Kualitas Materi Ajar
}

\author{
Merli Yuridha \\ Universitas Negeri Padang \\ E-Mail: Merliyuridha107@gmail.com
}

Literasi merupakan salah satu aspek penting yang harus kita ketahui. Literasi dari waktu ke waktu sudah banyak mengalami perubahan. Menurut (Alfin, 2018) dalam perkembanganya literasi harus mendapat perhatian. Literasi merupakan kemampuan dasar yang harus dikuasai oleh setiap indivdu. Perhatian terhadap literasi untuk meningkatkan kemampuan belajar siswa di masa depan. Literasi banyak dimuat dalam mata pelajaran di sekolah. Salah satunya dalam belajar bahasa Indonesia. Salah satu aspek literasi yang terdapat dalam pembelajaran bahasa Indonesia. Dalam praktiknya, Pembelajaran Bahasa Indonesia berfokus pada empat aspek keterampilan yang membutuhkan kreativitas guru untuk mencapainya hasil belajar yang baik. Keempat aspek keterampilan tersebut juga diperlukan untuk mempelajari mata pelajaran lain. Setiap aspek keterampilan berbahasa Indonesia saling terkait satu sama lain. Misalnya, seseorang dapat berbicara karena ia mampu mendengarkan, atau terampil membaca, dan menulis. Demikian pula orang yang terampil menulis, jika ia terampil mendengarkan, berbicara, dan membaca. Setiap keterampilan saling terkait satu sama lain.(Novelti et al., 2018)

Hasil belajar yang baik tidak terlepas dari proses dan materi ajar yang baik. Menurut (Mulyadi et al., 2020) belajar merupakan hubungan antara guru dengan siswa untuk saling bertukar pikiran berdasarkan pengalaman peserta didik sehingga hasil pembelajaran tercapai secara maksimal. Pada proses pembelajaran orientasi tidak lagi berpusat kepada guru, akan tetapi siswa yang lebih dituntut untuk aktif. Sehingga guru dituntut mampu memiliki kompetensi yang mampu mengarahkan peseta didik agar mudah memahami materi ajar. Kompetensi profesional seorang guru dengan memiliki kompetensi tersebut antara lain dapat mengembangkan profesionalisme secara berkelanjutan dengan melakukan tindakan reflektif, dan menggunakan TIK untuk berkomunikasi dan mengembangkan diri. Artinya, pelatihan publikasi ilmiah bagi guru merupakan pengembangan profesional dalam bentuk karya sebagai tindakan reflektif bagi guru profesional (Agusrida et al., 2020). Selanjutnya (Syahrul, 2020) menjelaskan perkembangan teknologi yang canggih akan mengujieksistensi guru profesional dengan kemampuannya menggunakan media dan sumber belajar berbasis digital. Hal ini karena kemampuan TIK merupakan suatu keharusan yang dimiliki seorang guru.

Pembelajaran bahasa Indonesia di setiap jenjang pendidikan mulai dari sekolah dasar hingga jenjang selanjutnya berorientasi pada peningkatan kemampuan berbahasa Indonesia para siswa (Sucia et al., 2020). Peningkatan kemampuan tersebut harus berbanding lurus dengan peningkatan materi ajar. Salah satu cara untuk meningkatkan kualitas materi ajar adalah dengan menggunakan media pembelajaran. Media pembelajaran berbasis teknologi dapat menumbuhkan sikap positif siswa terhadap materi dan proses pembelajaran Salah satu media yang digunakan dalam literasi baca tulis adalah modul electronic. (Indriyani et al., 2018) menjelaskan bahwa modul pembelajaran sangat penting dalam pembelajaran menulis. Modul pembelajaran yang dikembangkan berbasis problem based learning (PBL) sejalan dengan pendekatan saintifik dan pembelajaran berbasis teks. 
Dalam pembelajarn bahasa Indonesia, pembelajaran yang digunakan berdasrkan dengan teks. (Indriyani et al., 2019) Pada pembelajaran bahasa Indonesia, kurikulum yang digunakan adalah berbasis teks. Beberapa tahun kemudian, untuk mewujudkan visi dan misi agar masyarakat dapat beradaptasi dengan kemajuan pengetahuan dan teknologi, pemerintah mengeluarkan kebijakan tentang Gerakan Literasi Sekolah (GLS) dan diperbarui dengan Gerakan Literasi Nasional (GLN) Dengan demikian, PBL yang dijadikan dasar pengembangan modul ini membutuhkan pembelajaran menulis teks. Hal ini akan memudahkan guru dalam melaksanakan proses belajar mengajar. Dalam penggunaan modul tersebut peranan literasi baca tulis juga sangat berpengaruh.

\section{Referensi}

Agusrida, Atmazaki, Syahrul, R., \& Ermanto. (2020). Effectiveness of Online Scientific

Publication Training Approach for Teacher's Professional Competence Development at Religious Training Centre in Padang. 504(ICoIE), 370-375.

https://doi.org/10.2991/assehr.k.201209.251

Alfin, J. (2018). Membangun Budaya Literasi dalam Pembelajaran Bahasa Indonesia Menghadapai Era Revolusi Industri 4.0. PENTAS: Jurnal Ilmiah Pendidikan Bahasa Dan

$\begin{array}{lll}\text { Sastra } & \text { Indonesia, } & \text { 60-66. }\end{array}$ https://jurnal.univpgripalembang.ac.id/index.php/Prosidingpps/article/view/2511

Indriyani, V., Asri, Y., \& Ramadhan, S. (2018). Learning Module Design Writing Argumentative Text Based Problem-Based Learning. 263(Iclle), 194-200. https://doi.org/10.2991/iclle18.2018 .32

Indriyani, V., Zaim, M., Atmazaki, A., \& Ramadhan, S. (2019). Literasi Baca Tulis Dan Inovasi Kurikulum Bahasa. KEMBARA: Jurnal Keilmuan Bahasa, Sastra, Dan Pengajarannya, 5(1), 108. https://doi.org/10.22219/kembara.vol5.no1.108-118

Mulyadi, Syahrul, R., Atmazaki, \& Agustina. (2020). The Development of E-Modules Based on Adobe Flash for Indonesian Subjects at IAIN Bukittinggi. Journal of Physics: Conference Series, 1471(1). https://doi.org/10.1088/1742-6596/1471/1/012002

Novelti, N., Ramadhan, S., Ermanto, E., \& Agustina, A. (2018). Developing an Instructional Model Assisted Audio Visual Media. 263(Iclle), 111-116. https://doi.org/10.2991/iclle18.2018.17

Sucia, Ramadhan, S., Asri, Y., Padang, N., \& Padang, N. (2020). Pengembangan Modul Elektronik Berbasis Discovery Learning dalam Menulis Teks Eksplanasi. 463, 63-69.

Syahrul, R. (2020). Efektifitas Pendekatan Diklat Publikasi Ilmiah Online Untuk Pengembangan Kompetensi Profesional Guru di Balai Diklat Agama Padang. 504(ICoIE), 370-375. 


\title{
The Effect of Reading and Writing Literacy in Improving the Quality of Teaching Materials
}

\author{
Merli Yuridha \\ Universitas Negeri Padang \\ E-Mail: Merliyuridha107@gmail.com
}

Literacy is one of the important aspects that we must know. Literacy from time to time has undergone many changes. According to (Alfin, 2018) in its development literacy must receive attention. Literacy is a basic skill that must be mastered by every individual. Attention to literacy to improve student learning abilities in the future. Literacy is widely included in subjects at school. One of them is learning Indonesian. One aspect of literacy contained in learning Indonesian. In practice, Indonesian Language Learning focuses on four aspects of skills that require teacher creativity to achieve good learning outcomes. These four aspects of skills are also needed to study other subjects. Every aspect of Indonesian language skills is interrelated with each other. For example, a person can speak because he is able to listen, or is skilled at reading, and writing. Likewise, a person who is skilled at writing, if he is skilled at listening, speaking, and reading. Each skill is interrelated with one another. (Novelti et al., 2018)

Good learning outcomes can not be separated from the process and good teaching materials. According to (Mulyadi et al., 2020) learning is a relationship between teachers and students to exchange ideas based on the experiences of students so that learning outcomes are achieved optimally. In the learning process, orientation is no longer centered on the teacher, but students are more required to be active. So that teachers are required to be able to have competencies that are able to direct students to easily understand the teaching material. Professional competence of a teacher by having these competencies, among others, can develop professionalism in a sustainable manner by taking reflective actions, and using ICT to communicate and develop themselves. This means that scientific publication training for teachers is a professional development in the form of work as a reflective action for professional teachers (Agusrida et al., 2020). Furthermore (Syahrul, 2020) explained that the development of sophisticated technology will test the existence of professional teachers with their ability to use digital-based media and learning resources. This is because ICT skills are a must for a teacher.

Learning Indonesian at every level of education starting from elementary school to the next level is oriented towards improving students' Indonesian language skills (Sucia et al., 2020). The increase in these abilities must be directly proportional to the increase in teaching materials. One way to improve the quality of teaching materials is to use learning media. Technology-based learning media can foster a positive attitude of students towards the material and the learning process. One of the media used in literacy is the electronic module. (Indriyani et al., 2018) explains that the learning module is very important in learning to write. The learning module developed is based on problem based learning (PBL) in line with the scientific approach and text-based learning.

In learning Indonesian, the learning used is based on the text. (Indriyani et al., 2019) In learning Indonesian, the curriculum used is text-based. Several years later, to realize the vision and 
mission so that society can adapt to advances in knowledge and technology, the government issued a policy on the School Literacy Movement (GLS) and updated it with the National Literacy Movement (GLN). write text. This will facilitate the teacher in carrying out the teaching and learning process. In using this module, the role of literacy is also very influential.

\section{Referensi}

Agusrida, Atmazaki, Syahrul, R., \& Ermanto. (2020). Effectiveness of Online Scientific Publication Training Approach for Teacher's Professional Competence Development at

Religious Training Centre in Padang. 504(ICoIE), 370-375. https://doi.org/10.2991/assehr.k.201209.251

Alfin, J. (2018). Membangun Budaya Literasi dalam Pembelajaran Bahasa Indonesia Menghadapai Era Revolusi Industri 4.0. PENTAS: Jurnal Ilmiah Pendidikan Bahasa Dan Sastra Indonesia, 4(2), 60-66. https://jurnal.univpgripalembang.ac.id/index.php/Prosidingpps/article/view/2511

Indriyani, V., Asri, Y., \& Ramadhan, S. (2018). Learning Module Design Writing Argumentative Text Based Problem-Based Learning. 263(Iclle), 194-200. https://doi.org/10.2991/iclle-18.2018.32

Indriyani, V., Zaim, M., Atmazaki, A., \& Ramadhan, S. (2019). Literasi Baca Tulis Dan Inovasi Kurikulum Bahasa. KEMBARA: Jurnal Keilmuan Bahasa, Sastra, Dan Pengajarannya, 5(1), 108. https://doi.org/10.22219/kembara.vol5.no1.108-118

Mulyadi, Syahrul, R., Atmazaki, \& Agustina. (2020). The Development of E-Modules Based on Adobe Flash for Indonesian Subjects at IAIN Bukittinggi. Journal of Physics: Conference Series, 1471(1). https://doi.org/10.1088/1742-6596/1471/1/012002

Novelti, N., Ramadhan, S., Ermanto, E., \& Agustina, A. (2018). Developing an Instructional Model Assisted Audio Visual Media. 263(Iclle), 111-116. https://doi.org/10.2991/iclle-18.2018.17

Sucia, Ramadhan, S., Asri, Y., Padang, N., \& Padang, N. (2020). Pengembangan Modul Elektronik Berbasis Discovery Learning dalam Menulis Teks Eksplanasi. 463, 63-69.

Syahrul, R. (2020). Efektifitas Pendekatan Diklat Publikasi Ilmiah Online Untuk Pengembangan Kompetensi Profesional Guru di Balai Diklat Agama Padang. 504(ICoIE), 370375. 